\title{
アイントープ実験施設の設計 $(\mathrm{I})^{\dagger}$
}

\author{
は じ め に \\ 藤 井 正一 \\ 芝浦工業大学建築工学科 \\ 東京都港区芝浦3-9-14
}

RI の使用にあたっては，RI から放射される放射線 に被曝すると，健康上のみならず遺伝的にも重大な障 害があらわれることから，各国ともにその使用方法を 厳重にとりしまっている。わが国に抒いては，「放射 線障害防止法」の規定によって，RI 使用の許可をうる ためには，RI 使用に対する資格を有する「放射線取扱 主任者」が管理をしていることと，RI 使用に適した 「RI 使用施設」をそなえていることが必要である。し たがって，RI 使用施設は放射線障害を防止するため に，一般の実験施設とはかなり異なったいろいろの特 殊な配虑が必要である。

このような RI 実験施設の設計ということは, RI の 利用が広い範囲にわたって行なわれはじめた昭和 30 年 ころからの数年間はいろいろ興味をもたれ，本誌にお いてもしばしば取り上げられた。しかし，最近の 10 年 くらいは，ほとんど RI 実験施設についての議論や研 究は影をひそめ, 雑誌などに掲載されている記事は非 常に少ない。

最近，RI の利用が新しい段階にはいり，従来とは かなり異なった利用法も行なわれはじめているし，施 設についての経験も積まれている。この意味から，新 たにそれぞれの分野の専門家に分担していただいて，

RI 実験施設の 設計について解説することになった。 今回とり扱ら範囲は，主として非密封の RIを用い るいわゆる污染のおそれのある施設であるが，一部で はラジオグラフィを併用している施設もかなりあるの で，小さな照射施設も含めて解説することにした。 近年, 病院や診療所での診断や治療への RI の利用
がますます発展して，医療方面に打ける RI の使用は その種類も量も急激に増加している。これにともなっ て, 医療用の $\mathrm{RI}$ 利用施設の新しいものが数多く建設 されている。この点については，アイソトープ協会で 発行している「医療用アイソトープ使用施設設計基準 資料」が近々改訂されて出版されることになっている ので，今回の講座から除くことにした。この方面のこ とについて必要な方々は，この改訂版をご覧いただき たい。

本講座は, 現在の予定では 6 回にわたって, 大体つ ぎのような内容で記述されることになっている。

総論
1. 施設の計画と構成
2. 各室の配置
3. 各室の構造

各論.

1. モニター機器および安全設備

2. 表面仕上げ

3. 給排水施設

4. 給排気施設 (フードを含む)

5. 乙ゃへい（遠隔操作用具を含む）

内容については，なるべく具体的事項について，新 しい知識を盛り込むようにしたいと考えている。今後 RI 実験施設を計画される方々はもちろん，現在使用 されている施設をいっそう有效に利用しようという方 々にとって，いくらかのご参考になれば筆者一同幸と するところである。

$\dagger$ Design of Radioisotope Laboratory (I) Introduction, Seiichi FuJII: Department of Architectural Engineering, Shibaura Institute of Technology, Shibaura, Minato-ku, Tokyo. 